University of Michigan Law School

University of Michigan Law School Scholarship Repository

1999

\title{
Minority Preferences Reconsidered
}

\section{Terrance Sandalow}

University of Michigan Law School, sandalow@umich.edu

Available at: https://repository.law.umich.edu/reviews/47

Follow this and additional works at: https://repository.law.umich.edu/reviews

Part of the Civil Rights and Discrimination Commons, Education Law Commons, Fourteenth

Amendment Commons, Law and Race Commons, and the Law and Society Commons

\section{Recommended Citation}

Sandalow, Terrance. "Minority Preferences Reconsidered." Review of The Shape of the River: Long-Term Consequences of Considering Race in College and University Admissions, by W. G. Bowen and D. Bok. Mich. L. Rev. 97, no. 6 (1999): 1874-916.

This Review is brought to you for free and open access by the Faculty Scholarship at University of Michigan Law School Scholarship Repository. It has been accepted for inclusion in Reviews by an authorized administrator of University of Michigan Law School Scholarship Repository. For more information, please contact mlaw.repository@umich.edu. 


\title{
MINORITY PREFERENCES RECONSIDERED
}

\author{
Terrance Sandalow*
}

The Shape of the River: Long-Term Consequences of Considering Race in College and University Admissions. By William G. Bowen and Derek Bok. Princeton: Princeton University Press. Pp. xxxvi, 472. \$24.95.

During the academic year 1965-66, at the height of the civil rights movement, the University of Michigan Law School faculty looked around and saw not a single African-American student. The absence of any black students was not, it should hardly need saying, attributable to a policy of purposeful exclusion. A black student graduated from the Law School as early as 1870 , and in the intervening years a continuous flow of African-American students, though not a large number, had been admitted and graduated. Some went on to distinguished careers in the law.

But with the rise in the number of young people seeking admission to law school that began in the 1960 s, admission standards at Michigan and at other law schools rose significantly. The consequence was that during the three-year period beginning in 1963 not a single black applicant qualified for admission to the Law School. In response to that dismal fact, the faculty directed its admission officer to recruit black applicants and, if necessary to achieve a reasonable number of blacks in the student body, to admit black applicants who seemed likely to complete the School's program whether or not they satisfied the admission standards required of other applicants.

Similar programs were adopted at about the same time by a few other law schools and by a number of undergraduate schools. Within a few years, say by 1970 , the use of racial and ethnic criteria in college and university admissions was widespread. ${ }^{1}$ During the

* Edson R. Sunderland Professor of Law, University of Michigan. A.B. 1954, J.D. 1957, University of Chicago. Professor Sandalow served as Dean of the University of Michigan Law School from 1978 to 1987 . - Ed. I am grateful to Peter O. Steiner for helpful comments on a draft of this review. As he would be the first to insist, I am solely responsible for any errors that remain.

1. Race-sensitive admission policies were not, of course, novel in American colleges and universities. Many, by no means limited to those located in the South, had taken account of race (and religion and ethnicity) for the purpose of excluding blacks and members of other minority groups from their student bodies. See, e.g., Marcta Graham SxNOTT, The HaLFOPENED DOOR (1979). The novel feature of the programs initiated in 1965 and thereafter was that they employed racial and ethnic criteria to increase the representation of blacks and others in the student body. 
1970s, race-sensitive policies became a pervasive feature of American life, at least in its largest and most influential institutions, extending also to financial aid programs, employment and promotion decisions in both the public and private sectors, governmental and corporate procurement programs, and decisions about the apportionment of legislative bodies.

Although the intensity of the debate has waxed and waned over the years, the legality and the wisdom of the policies have been sources of continuing controversy from their inception. Curiously, considering the amount of attention the policies have received from the public generally, and the academic community in particular, little is known about their consequences. In The Shape of the River, William Bowen and Derek Bok, the former presidents, respectively, of Princeton and Harvard, undertake to inform one important corner of the currently intense debate about minority preferences by presenting the results of the first comprehensive study of the consequences of those preferences in undergraduate education. ${ }^{2}$ The study draws mainly upon the rich storehouse of information contained in the College and Beyond (C\&B) database compiled by the Andrew W. Mellon Foundation, of which Bowen is currently president. The portion of the database on which they draw includes the records of all undergraduate students who matriculated in the fall of 1951, the fall of 1976, and the fall of 1989 at twenty-eight selective colleges and universities, institutions that are generally representative of the undergraduate schools at which race-sensitive policies play a role in the selection of students. Bowen and Bok supplement the $C \& B$ database with information obtained by surveying $\mathrm{C} \& \mathrm{~B}$ matriculants to determine, inter alia, the course of their lives after college and how they viewed their college experiences (pp. xxvii-xxx). By studying the 1976 and 1989 entering classes, they are able to ascertain not only the effect of racesensitive admission policies upon the composition of the entering classes, but also to learn a great deal about the achievements of those studied both during and after college. The result is a treasure

2. The study is limited to undergraduate education. As the authors recognize, the issues posed by minority preference policies may differ across the several areas in which they have been adopted. See p. xxv. Of course, the claim that the policies pose different issues in different contexts would not be accepted by those who support or oppose the policies for reasons of moral principle that do not depend on consequential arguments, such as that all racial distinctions are immoral or that the policies are required by principles of compensatory justice.

The study is limited in one other important respect. Although information about Hispanics is occasionally included, Bowen and Bok focus almost entirely on the consequences of the policies for African Americans, advancing a number of practical justifications for the omission of other beneficiaries. See pp. xxvi-xxvii. The omission is justified, in my view, for a quite different reason: The policies were initially adopted because of, and I believe the primary impetus for their retention remains, the perceived importance of increasing black enrollment in colleges and universities. 
trove of information about the consequences of minority preferences in undergraduate education.

The authors do not claim that an appreciation of those consequences will or should end the debate about either the legality or the wisdom of the policies. "Plainly," as they write, "data take us only so far in considering this subject" (p. xxiv). Proponents and opponents each make arguments of moral principle unaffected by facts. Moreover, data is often subject to differing interpretations. And, finally, no study of an issue as complex and as controversial as preferential admissions in higher education is likely to satisfy the disputants that all the relevant data has been collected. Still, increased knowledge of the consequences of the programs cannot fail to affect the terms of the debate and, perhaps, to modify the views of those who participate in it. Although many of Bowen and Bok's findings will be unsurprising to academics and others who have been immersed in the issues, the impressive array of data they report and analyze puts a much firmer foundation under what the latter may suppose they already "knew." And even experts may find that some of what they thought they knew is contradicted, or at least unsupported, by the available data. The audience likely to gain most from the book, however, is the far larger number of academics and those members of the general public whom three members of the Supreme Court have aptly described as "the thoughtful part of the Nation,"3 those who understand that knowledge is relevant to judgment and that approval or disapproval of a policy ought to be grounded in reasons.

Members of both groups, however, would do well to approach the book with some care. What Bowen and Bok have written is, in many ways, a brief for the continuation of the policies whose consequences they are examining. As they acknowledge at the outset, both have for many years strongly supported race-sensitive admission policies. That support colors their analysis at nearly every point, affecting not only the conclusions they reach but the questions they ask of the data and the matters to which they draw the attention of readers. In saying that, I do not intend to suggest that they have unfairly defined the relevant issues or unfairly reported the data they have gathered. To the contrary, they are at pains to bring to the surface information other proponents have often sought to submerge and to identify possible interpretations of the evidence that differ from their own. But in doing so, they invariably attempt to lead readers to the conclusion that "academically selective colleges and universities have been highly successful in using race-sensitive admissions policies to advance educational goals im-

3. Planned Parenthood v. Casey, 505 U.S. 833, 864 (1992) (opinion of O'Connor, Kennedy, and Souter, JJ.). 
portant to them and societal goals important to everyone" (p. 290). In fact, as I shall attempt to demonstrate in the pages that follow, the evidence bearing upon the success of the policies and the wisdom of retaining them is a good deal more ambiguous than they seek to persuade readers.

\section{The Shape of the Evidence}

\section{A. The Effect of Racial Preferences on the Composition of the Entering Class}

An observer of higher education unfamiliar with the history of preferential admission policies for minorities might think it ironic that the policies originated at the end of a decade in which the nation - speaking through all three branches of its government had adopted wide-ranging policies aimed at creating a "color-blind" society. At the outset, however, many who supported race-sensitive admission policies believed, not without reason, that those policies did not discriminate on the basis of race. Traditional predictors of academic success, it was commonly argued, might not be accurate for blacks. Admission tests, such as the SAT, were plausibly believed to be culturally biased. Moreover, since many blacks had attended inferior schools, their failure to perform well on the tests might reflect only an educational deficiency that could be overcome by remedial courses at the college level.

Although some proponents of racial preferences continue to make such claims, experience gained in the intervening years demonstrates their invalidity. We now know that the most common predictors of academic success, SAT scores and high school grades, do not underpredict the performance of blacks in college. To the contrary, at every level blacks underperform whites with equivalent SAT scores and high school grades. ${ }^{4}$ In other words, if probable success in college, as measured by grades, were the sole basis for deciding among applicants, race would count against blacks, not in their favor.

Consequentialist arguments for admitting blacks unlikely to perform as well as the whites and Asian Americans who would have been admitted if race were not considered necessarily begin with

4. See pp. 76-78. The finding that African Americans underperform whites with equivalent SAT scores holds even when a range of other variables, e.g., gender, socioeconomic status, field of study, etc. are taken into account. See id. On the magnitude of the overprediction, see infra note 26. See also Frederick E. Vars \& William G. Bowen, Scholastic Aptitude Test Scores, Race, and Academic Performance in Selective Colleges and Universities, in THE BLACK-WhITE TEST SCORE GAP 457, 466 (Christopher Jencks \& Meredith Phillips eds., 1998). Studies of the predictive value of the Law School Admission Test yield a similar finding. See Linda F. Wightman, The Threat to Diversity in Legal Education: An Empirical Analysis of the Consequences of Abandoning Race as a Factor in Law School Admission Decisions, 72 N.Y.U. L. REv. 1, 29 (1997) (citing studies). 
the effect of a race-neutral admission policy on African-American college enrollment. 5 Bowen and Bok estimate that race plays a significant role in admission decisions at only 20 to $30 \%$ of four-year undergraduate institutions. "[T]he vast majority of undergraduate institutions accept all qualified candidates and thus do not award special status to any group of applicants, defined by race or on the basis of any other criterion" (p. 15). Abandoning racial preferences would not, thus, necessarily lead to a significant, or indeed any, reduction in overall black college enrollment. ${ }^{6}$ Blacks currently admitted to selective institutions who were unable to meet the admission criteria for whites and Asian Americans might simply attend institutions that admit all qualified applicants. ${ }^{7}$

The most important questions that The Shape of the River addresses, accordingly, are those that concern the consequences for the students of all races who attend selective undergraduate institutions, and for the larger society, of policies that promote the attendance of African Americans at those institutions. ${ }^{8}$ The initial consequence is that a nationwide abandonment of the policies would lead to a dramatic reduction in the number of blacks attending those institutions. ${ }^{9}$

5. The effect of any such policy obviously depends upon the criteria it employs. Thus, a race-neutral policy that favors the children of alumni or the graduates of the nation's topranked high schools will produce a student body with a different racial mix than would a policy that favors applicants from low-income and working-class families. The discussion that follows assumes that colleges would retain their current admission policies, except insofar as the policies are race-sensitive. For brief consideration of the effects of other race-neutral policies, see infra note 12 .

6. Just how the elimination of racial preferences would affect total black undergraduate enrollment is probably unknowable. Selective colleges and universities typically have markedly greater resources for financial aid than unselective institutions, and graduation from them offers significantly greater rewards. We have no way of knowing how these factors, and perhaps others, would affect college attendance by those blacks currently admitted to selective institutions who would be denied admission under race-neutral criteria.

7. The possibility that black enrollment might simply be shifted from more to less selective institutions is significantly reduced, and perhaps eliminated, in professional and graduate fields in which the number of applicants is sufficiently high that virtually all institutions are selective. In such fields, abandoning race-sensitive admission policies would mean a reduction, quite possibly a very significant reduction, in the number of blacks trained for work in the field. See infra text accompanying notes 37-42.

8. I have addressed elsewhere my reasons for believing that the consequences for white and Asian-American students who would have been admitted but for current racial preference policies are not an important element in a judgment about the desirability of the policies. See Terrance Sandalow, Racial Preferences in Higher Education: Political Responsibility and the Judicial Role, 42 U. CHI. L. REv. 653, 674-75 (1975).

9. At present, a nationwide abandonment of such policies seems plausible only if the Supreme Court holds them to be illegal. In Hopwood v. Texas, 78 F.3d 932 (5th Cir. 1996), cert. denied, 518 U.S. 1033 (1996), the court held that the Equal Protection Clause of the Fourteenth Amendment prohibits state colleges and universities from employing race-sensitive admission policies. Cases raising the same issue are currently pending against the University of Michigan and the University of Washington. (The latter case may have been mooted by a recent state ballot measure prohibiting state institutions from adopting racial preference policies.) It may not be widely appreciated that under current law a decision by 
Although selective institutions consider many factors in deciding which applicants to admit, the single most important is the likelihood of success in the school's academic program. The best and most widely used predictors of academic success are the applicant's SAT scores and his or her high school grades. Each is significantly correlated with academic performance in college, but the two taken together are a better predictor than either considered alone. ${ }^{10}$ By any of these measures, however, African Americans do not fare well in comparison with whites and Asian Americans. Both their SAT scores and high school grades are, on average, considerably lower than those of the latter two groups.

Because of the difficulties in comparing high school grades from many institutions with widely variant standards, Bowen and Bok consider only SAT scores in comparing the credentials presented by black and white applicants. ${ }^{11}$ In 1989, the most recent year included in their study, the mean scores of all white test-takers were approximately 440 on the verbal part of the test and approximately 495 on the math part (p. 19). The comparable scores for blacks were approximately 350 and 390 , a difference of 90 points on the verbal and 105 points on the math (p. 19). Both black and white college applicants are, of course, roughly aware of the admission standards of colleges in which they might be interested and presumably do not apply to institutions at which they have a small chance of being admitted. The average SAT score of the pool of applicants to selective institutions is, therefore, considerably higher than the national averages for both blacks and whites. Unfortunately, Bowen and Bok have adequate data for only five of the twentyeight institutions in their sample. They represent, however, that these five institutions are "roughly representative" of the larger sample (p. 17 n.4). In 1989, the most recent year included in their study, the average combined verbal and math scores for white applicants to these institutions was 1284 . The corresponding score for black applicants was 1098, resulting in a gap equivalent to that for the national pools (p. 29).

the U.S. Supreme Court reaching the same result as that reached in Hopwood would require private colleges and universities as well as public ones to terminate their current policies. As interpreted by the Supreme Court, Title VI of the 1964 Civil Rights Act, 42 U.S.C. $\$ 2000$ d, which prohibits racial discrimination by recipients of federal funds, incorporates the Equal Protection Clause's standard for determining when racial discrimination is permissible. See Regents of the Univ. of Cal. v. Bakke, 438 U.S. 265 (1978). All selective institutions are recipients of federal funds and, thus, subject to Title VI.

10. See pp. 74-76; The College Board Handbook For the SAT® Program 1998-99, at 32 (1998).

11. The authors have apparently excluded Asian Americans from this and other comparisons made throughout the book. In view of the large number of Asian Americans who apply to and matriculate at selective institutions, and the success that they achieve, the exclusion may have a distorting effect on the book's comparisons of blacks admitted because of racesensitive admissions and other students. 
Confronted with a difference of this magnitude in the black and white applicant pools, selective institutions have only two realistic options. ${ }^{12}$ They can either adopt race-blind admission policies, denying admission to all but a few black applicants, or they can take race into account in order to achieve a reasonable representation of blacks in their student bodies. All have adopted the latter course. The inevitable consequence is a very substantial disparity between the SAT scores of black and white matriculants. At the five schools on which Bowen and Bok base this part of their analysis, the average SAT score of white matriculants was 1331, while that for blacks was 1157 (p. 29). The resulting gap of 174 points was quite similar to the black-white differences in the applicant pools and in the averages of all test-takers. ${ }^{13}$

Critics of race-sensitive admission policies have often pointed to the size of that gap in support of one or another objection to the policies. Bowen and Bok correctly point out, however, that not all of the gap is attributable to preferential admission policies. Because black applicants generally have lower SAT scores than whites, some gap would exist even if race did not enter into the admission decision (p. 16). Precisely how much racial preference contributes to the gap may well be unknowable because of uncertainty about the scores of the white and Asian-American students who would have been admitted in place of the blacks whose admission is attributable to their race. ${ }^{14}$ The data presented by Bowen and Bok strongly suggest, however, that race preferences make a significant contribution to the size of the gap. That conclusion is an appropriate inference from the data they report regarding the comparative prospects for admission of blacks and whites in various SAT score ranges. Thus, a black applicant with a score between 1400 and 1449 had nearly a $75 \%$ chance of admission, while a white with a comparable score had approximately a $40 \%$ chance. In the 1250-1299 range, the odds that a black applicant would be admitted

12. One can, of course, imagine a large number of options, but all suffer from one or more of the following drawbacks: they would not result in a substantial representation of African Americans, they would exclude those African Americans most likely to succeed, or they would radically alter the character of the institutions.

13. Proponents of racial preferences often point to the preference given to "legacies," applicants whose parents or other family members have attended the institution. Bowen and Bok do not report the average SAT scores for matriculants who are legacies, but it is clear from the data they do provide that the advantage enjoyed by legacies is quite significantly less than that afforded African Americans. Illustratively, in the SAT score range of 11001199 , the range which includes the average and modal scores of black matriculants, the acceptance rate was $22 \%$ for legacies, compared with $18 \%$ for other whites and approximately $40 \%$ for blacks (p. 28). (These percentages are drawn from only three of the five schools; elsewhere, Bowen and Bok report that the acceptance rate at all five schools for blacks in this range was approximately $50 \%$ (p. 27 fig.2.5).)

14. A review of the credentials of white and Asian-American applicants on the "waiting lists" of the schools might permit at least a rough judgment. 
remained at the $75 \%$ level, while the odds for white applicants dropped below $25 \%$. The comparable percentages for applicants with scores between 1100 and 1149 were approximately $15 \%$ for whites and just under $50 \%$ for blacks. Viewing the same data from a slightly different perspective, the odds were approximately even that black applicants with scores between 1100 and 1199 would be admitted. The odds for whites did not reach that level until they had scores in the 1450-1499 range (p. 27 fig.2.5).

Race-sensitive admission policies thus appear to make a significant contribution to the gap between the SAT scores of black and white matriculants, an inference strongly supported by a recent study which concludes that "African-American applicants [to selective institutions] enjoy an advantage equivalent to an increase of two-thirds of a point in high school grade point average (GPA) on a four-point scale - or 400 points on the SAT." 15 Yet, Bowen and Bok maintain otherwise. They calculate that the mean SAT score of blacks who would have matriculated at the five schools absent racial preferences would have been only 24 points higher than that of the larger number of blacks who actually matriculated. The increase, from 1157 to 1181 , would have reduced the black-white gap by less than $15 \%$ (p. 42 ). But that calculation, as the next several paragraphs attempt to demonstrate, is based upon an overly optimistic estimate of the number of blacks who would have been admitted and matriculated. A more realistic estimate would almost certainly have yielded a cohort of black matriculants with significantly higher SAT scores than those of the larger group Bowen and Bok assume would have been admitted.

Although it is certain that terminating race-sensitive admission policies would dramatically reduce the number of African Americans attending selective colleges and universities, estimating how many would remain in those institutions is not a simple task. SAT scores play an important role in deciding which applicants to admit, but they are far from the only factors that influence admission decisions. As Bowen and Bok emphasize, racial considerations aside, admission officers take account of a variety of other factors, for example, other predictors of academic success, a range of other talents (such as musical or athletic talent), experiences and backgrounds that will add to the mix within the student body and thereby enrich the educational environment, and the relationship of the applicant's family to the institution (pp. 23-26). Given the multiplicity of considerations that enter into admission decisions, it is impossible to determine how many African Americans would have

15. Thomas J. Kane, Racial and Ethnic Preferences in College Admissions, in THE BLACKWhite Test SCORe GAP, supra note 4, at 431, 432. 
been admitted under race-neutral policies without reexamining the applications of the entire applicant pool.

Since that plainly would not have been feasible, Bowen and Bok adopt another, "common sense" approach. To determine how many blacks would have matriculated at the five schools under a race-neutral admission policy, they assume that "black applicants, grouped by SAT ranges, would have the same probability of being admitted as white applicants in those same ranges."16 On that basis, they conclude that the percentage of blacks in the 1989 entering classes of the five schools would have been reduced by $50 \%$, from $7.1 \%$ to $3.6 \%$ (p. 35). Similar results obtain when national SAT data is applied to all twenty-eight schools in the larger sample the authors employ for most of their analysis. However, simulations based on the larger sample tell an even more troubling story. Bowen and Bok divide the twenty-eight institutions into three groups, depending on their selectivity (as measured by average SAT scores). In the most selective group (SEL-1), those in which the average SAT score of the 1989 entering class was above 1300, they estimate that the percentage of black matriculants would have fallen from 7.8 to $2.1 \%$; in the second group (SEL-2), those with average SAT scores between 1150 and 1299, the percentage would have fallen from 5.8 to 2.8 ; and in the least selective of the selective schools (SEL-3), the percentage would have been reduced from 6.6 to 4.5 (p. 41 fig.2.11). Under a race-neutral admission policy, in other words, the most selective schools would have lost approximately three-quarters of their black students, the middle group would have lost more than half, and even the least selective would have lost approximately a third. The consequence, as Bowen and Bok write, "would presumably take black enrollments at many of these selective institutions most of the way back to early 1960 s levels, before colleges and universities began to make serious efforts to recruit minority students." 17

Startling as these projections are, they almost certainly overstate the representation of African Americans in selective institutions if race-neutral admission policies were to be employed. Bowen and Bok's method of estimating black admission rates would be entirely appropriate if we knew nothing more about the black and white applicant pools than their mean SAT scores. In that event, the only reasonable assumption would be that the two pools are the same in all other respects. But we do know more, and what we know makes

16. P. 31. The number of matriculants also depends on the "yield," i.e., the percentage of applicants admitted who accept a school's offer. The authors employ the same method in making that calculation. See pp. 32-35.

17. P. 39. A study of law school admissions for the year 1991 reaches a very similar conclusion. See infra text accompanying notes 39-42. The significant decline in law school applicants since 1991 may have altered the situation. 
it virtually certain that blacks would be admitted to selective institutions at a lower rate than they assume. The single most important criterion for admission is the applicant's predicted success, as measured by grades, in the school's academic program. In making that prediction, however, admission officers have much more to go on than SAT scores. As Bowen and Bok recognize at other points in their argument, admission officers also look at such factors as high school grades, the quality and grading standards of the schools at which they were earned, the number of and performance in advanced placement courses, and performance on achievement tests (pp. 28, 78).

An Asian-American or white applicant who has a relatively low score on the SAT is unlikely to be admitted unless the other predictors are especially promising. Conversely, an applicant from one of those groups who has a relatively high SAT score is unlikely to be admitted if the other predictors of academic success appear inconsistent with the SAT score. At each SAT level, however, the other evidence of probable academic success offered by black applicants is, on average, less favorable than that of whites and Asian Americans. ${ }^{18}$ For that reason, using the acceptance rates for whites to estimate the number of blacks who would have been admitted under a race-neutral policy is bound to inflate the estimate, probably significantly. ${ }^{19}$ This conclusion is supported by Bowen and Bok's own projections. Their estimates of the effect of race-neutral admission policies at all twenty-eight schools in their sample is based on the performance of black and white test-takers on the verbal SAT (p. $41 \mathrm{n} .28$ ). If, however, the projection had been based on the math portion of the exam, the estimated number of black matriculants would fall by nearly $20 \%$ (p. 351 tbl.B-5). The use of a combined score would, presumably, yield an intermediate estimate.

Two conclusions emerge from the foregoing analysis. First, were selective institutions required to adopt race-neutral admission policies, the percentage of African Americans in their student bodies would decline precipitously, certainly by not less than $50 \%$ and al-

18. Of course, other considerations that enter into the admission decision may have an offsetting effect. For example, to the extent that schools seek students who have overcome hardships or who come from lower socio-economic backgrounds, black applicants may disproportionately benefit. (A race-neutral policy would not, of course, permit giving weight to the hardship of overcoming race.) It is clear from the relative weights accorded such factors, on the one hand, and probable academic success, on the other, that the former would not greatly affect these estimates of the number of African-American matriculants at selective institutions.

19. A similar difficulty arises in using the white "yield" rate, see supra note 16 , to estimate the rate for blacks. The financial aid policies of some institutions take account of race in determining a student's financial aid package. The reduction in financial aid for black students that would result from adopting a race-neutral policy might well reduce the black "yield" in such institutions. 
most certainly by a significantly larger percentage. The decline would be steepest in the most selective schools, where enrollment would fall to between 1 and $2 \%$, but even in the least selective it would be reduced to $4.5 \%$ or less. ${ }^{20}$ Second, the level of AfricanAmerican representation in the 1989 entering classes of these institutions was achieved only by admitting African-American applicants whose academic credentials were not merely lower, but very significantly lower, than those of white and Asian-American admittees. Thomas Kane's estimate, that blacks enjoy an advantage of 400 points on the SAT or two-thirds of a point in high school grades, conveys some sense of the magnitude of the difference..$^{21}$

The implications of these empirical conclusions for policymakers pose agonizingly difficult questions. A discussion of those questions is best deferred until after a summary and analysis of some of Bowen and Bok's other findings, especially those that concern the consequences of race-sensitive admission policies for those black students who would not have been admitted if the policies had not been adopted.

\section{B. The College Performance of "Specially Admitted" Black Students 22}

The question immediately raised by the admission of a group of students whose academic credentials are so inferior to those of their classmates is whether they can succeed academically. If, as some critics of racial preferences maintain, the effect of the policies is to place "specially admitted" students into an environment in which they cannot be expected to succeed, the wisdom of the policies would be subject to serious question. If, on the other hand, those students are generally successful, a frequent objection to the policies would be shown to be groundless. Bowen and Bok argue that their findings support the latter conclusion, but the data they report is far more ambiguous than they claim. Although their data do provide some basis for the conclusion that black students benefit from

20. See p. 41 fig.2.11. The most selective institutions include such schools as Bryn Mawr, Duke, Princeton, and Yale; the least selective include such schools as the University of Michigan, Miami of Ohio, the University of North Carolina, and Tulane. For a complete list of the 28 selective institutions included in Bowen and Bok's study and their levels of selectivity, see p. 40.

21. See supra note 15 and accompanying text.

22. Many minority students object, with justification, to calling those students admitted because of race-sensitive policies "specially admitted" students. They are no more "specially admitted" than are those students admitted because they are legacies, athletes, musicians, or (for that matter) because they have especially impressive academic credentials. None of the criteria employed to select students are "natural"; each is a product of decisions concerning institutional and societal goals that must themselves be justified. I nonetheless use that locution because it is the one commonly employed and because of the awkwardness of the alternative. 
minority preference policies, critics of the policies are likely to find ample support for their belief that the policies produce a misfit between "specially admitted" students and the institutions in which they are enrolled.

One measure of success in college is graduation. Oddly, though Bowen and Bok regard that as an important measure, they seem to have made no effort to determine the graduation rate of "specially admitted" students. Rather, their discussion of graduation rates focuses on all black students. Of the black students who entered C\&B schools in 1989, they report, $75 \%$ graduated from the school they entered, and an additional $4 \%$ graduated from another institution, within six years (pp. 55-56). However, not all black matriculants were "special admits." Since graduation rates and college grades are positively correlated with SAT scores and other predictors of academic success (pp. 60, 63, 74-75), it seems a fair assumption that the graduation rate for "special admits" was somewhat lower than that for all African-American matriculants, though precisely how much lower cannot be determined from the data Bowen and Bok provide.

Although the attrition rate for "specially admitted" black students at C\&B schools compares very favorably with the attrition rate for all black students at a much larger set of institutions, and may even compare favorably with the attrition rate for whites at the latter institutions, ${ }^{23}$ it is significantly higher than the rate for Asian Americans and whites at C\&B schools. $88 \%$ percent of the former and $86 \%$ of the latter graduated from the school they entered within six years. Another $8 \%$ of each group graduated from a different school within the same time period (p. 56 fig.3.1). Comparative attrition rates are not, however, a very useful measure of whether race-sensitive admission policies lead to the admission of a significant number of unqualified students. Students leave school for many reasons (for example, financial difficulties, poor health, family problems, etc.) unrelated to academic performance. Bowen and Bok were, however, unable to obtain data on the reasons students in their sample had failed to graduate. Since SAT scores are positively correlated with graduation rates, especially in the lower ranges, academic reasons must have made some contribution to the withdrawal of many students from college, but the extent of the contribution is unclear. The difficulty of estimating the extent of the contribution is compounded by the fact that students who withdraw from school for academic reasons have not necessarily "flunked out"; a larger number are likely to have withdrawn be-

23. Of the students in the 1989 entering classes of the schools in Division I of the National Collegiate Athletic Association (NCAA), $59 \%$ of the whites and $40 \%$ of the blacks graduated from the institution they entered within six years. See p. 57. 
cause of frustration, or a loss of interest, attributable to the difficulty of the work. As Bowen and Bok point out, in these situations the student themselves may not know why they have "dropped out" (p. 55).

An additional difficulty with using graduation rates to measure the success of preferential admission policies is that the former are not independent of the latter. Institutional (and professorial) standards for determining the level that work must reach to be minimally acceptable is, as I shall discuss at a later point in more detail, a function of the quality of work students actually produce. Especially during the past several decades, the faculties of selective institutions have been highly resistant to awarding grades that might cause a student to "flunk out" of school. As one of my students, a graduate of one of Bowen and Bok's "most selective" institutions, recently put it: "It's not possible to flunk out at -.." Whether or not her perception is technically accurate, it is surely not very far from true. Of course, the reason may be that selective institutions are so skilled in deciding whom to admit that all of their students perform at a level that must be regarded as at least minimally competent, even when judged by standards one might expect at institutions that aspire to excellence. My own experience with the graduates of those institutions leads me to believe that the reluctance of faculties to put students on what was once called the "home list" is a more important factor.

For all these reasons, graduation rates are a very imperfect measure of the level of performance of "specially admitted" students. About all that can be said with confidence is that a substantial majority of the African-American students in that group do graduate. The "flip side of the coin" is that a substantial minority do not. Whether one views that as a measure of the success or of the failure of the policies depends upon whether one is inclined to see glasses, or at least this glass, as half-full or half-empty.

Grades might provide a more sensitive measure of the performance of "specially admitted" black students, but here too Bowen and Bok do not focus their inquiry on those students. The data they report are for all black students, at least some of whom, it should be borne in mind, would have been admitted under a raceneutral policy. But even the grades of this larger, bettercredentialed group of students present, in Bowen and Bok's words, a "sobering picture." Across all C\&B schools, the average class rank of black matriculants was at the twenty-third percentile of their classes. ${ }^{24}$ Almost certainly, however, the average class rank of

24. P. 72. To account for the fact that grading scales and grade inflation differ among the schools in their sample, the authors converted all grades into percentile ranks in class. See id. n.23. To the extent that different grading practices exist among disciplines, some distortions 
black students offers too rosy an estimate of the performance of all blacks who matriculated. Because of the very low mean, it is likely that well over half of the African-American students included in the computation scored below, many well below, the average. ${ }^{25}$ Moreover, since SAT scores and other predictors of academic success are correlated with graduation rates and with performance, as measured by grades, black students who withdrew from school are very likely to have had lower grades than those who are included in the computation of class rankings. ${ }^{26}$

For similar reasons, "special admits" included in the computation almost certainly had lower grades than those of their black classmates who would have been admitted under a race-neutral policy. For that reason, and because the students who withdrew are also more likely to have been "special admits," the overall performance of those matriculants who were admitted in consequence of race-sensitive admission policies is virtually certain to have been substantially worse than suggested by the finding that the mean rank of black students was at the twenty-third percentile. In consequence, it is difficult to perceive the basis for Bowen and Bok's conclusion that "[t]hese students certainly do not appear to have been 'over-matched' academically by their colleges and universities" (p. 88). Bowen and Bok are, to be sure, referring to all black students, but no one has suggested that all black students are incapable of competing academically with the white and AsianAmerican students at selective institutions. The question, as the subtitle of their book suggests, is whether the students admitted in virtue of their race are in the appropriate academic environment.

in the class rank of black students might arise if substantial differences exist in the majors elected by black and white students. One of the surprising findings of their study, however, is that the distribution of majors does not differ significantly across racial lines. The percentages of the two groups majoring in engineering, mathematics, and the natural sciences are almost identical. Black students are more likely than whites to major in one of the social sciences, while the latter are more likely to major in the humanities, but the differences seem unlikely to have a substantial effect on grades. See pp. 70-72.

25. The likelihood exists because a few black students who have a relatively high class rank will significantly raise the mean. Consider, for example, a group of nine black students in a class of 100 whose percentile ranks are $70,40,28,23,20,14,7,5$, and 1 . Only three of the nine would have a class rank above the mean of 23 .

26. Although Bowen and Bok state that the percentile rank they calculated was for all "matriculants," it is unclear whether they have included those who did not graduate or, if they have, how that was done.

One of the study's most troubling findings is that "black students in the C\&B schools [who were] equivalent to all C\&B students in their SAT scores, high school grades, socioeconomic status, and other characteristics included in the model (gender, selectivity of the school attended, field of study, being an athlete or not) . . . would [still] have had a class rank 16 percentile points lower than the class rank of apparently comparable classmates." P. 77. Bowen and Bok consider a variety of possible explanations for this puzzling phenomenon, but in the end conclude "the reasons for [the] underperformance are not entirely clear." $P$. 88. 
In sum, although precise calculations cannot be made from the data Bowen and Bok report, it seems reasonable to infer from that data that one-quarter to one-third of black "special admits" do not graduate and that a substantial majority of those who do, graduate in the bottom fifth of their classes. Critics of minority preference policies often argue that because of their relatively poor performance in selective institutions, "special admits" would be better off attending institutions at which their academic qualifications are similar to those of other students. Some support for that claim may be found in an interesting, if tangential, finding to emerge from Bowen and Bok's study:

Students who attended one of the SEL-1 schools paid, on average, a 'penalty' of almost 15 percentile points in class rank, as compared with the class rank earned by students with the same SAT scores and other attributes who went to an SEL-3 school. The comparable "penalty' paid by students who went to SEL-2 schools was 8 points in class rank.... [p. 73]

Students presumably pay a similar "penalty" for attending any of the selective schools rather than an unselective institution. Bowen and Bok maintain, nonetheless, that African-American students would not be better off attending less selective or unselective institutions, where their credentials are similar to those of other students, if success is measured by the likelihood of graduation. At every SAT level, their data show, the graduation rate of black students is higher, and at most levels substantially higher, at SEL-1 schools than at SEL-2 schools and higher at SEL-2 schools than at SEL-3 schools. ${ }^{27}$ The effect of school selectivity on graduation rates holds even after controlling for several other correlates of graduation rate - gender, high school grades, and socioeconomic status (pp. 61-63).

Bowen and Bok offer two primary explanations for these rather surprising findings. Both seem entirely plausible, but they have somewhat differing implications for evaluating the contention that black students would be better off at schools where the credentials of other students more closely match their own. First, the more selective schools, especially those in the SEL-1 grouping, tend to be residential, to have smaller enrollments and smaller classes, and to have greater resources for financial aid and support services - all factors that might be expected to contribute to high graduation rates. Marginal students, like those who benefit from minority preference policies, are especially likely to benefit from attending such institutions (pp. 63-64).

27. And it is higher at SEL-3 schools than it is at the NCAA's Division I schools. See supra note 23 . 
A second plausible explanation is that the more selective schools are able to identify applicants who are more likely to graduate than might be predicted from the factors for which Bowen and Bok controlled (p. 63). That is surely the case. As discussed above, admission officers take into account not only SAT scores and high school grades, but the quality and grading standards of the school at which the grades were earned, the number of and performance in advanced placement courses, and scores on achievement tests. ${ }^{28}$ In addition, the more selective institutions have a better opportunity than SEL-3 schools, mainly large state universities, to assess the quality of an applicant's writing, a time consuming task that is difficult to perform for the large number of applicants with which the latter institutions are confronted. Since nearly all applicants accept the offer of the most selective school by which they have been accepted (p. 42), students who appear especially promising on the basis of these criteria are highly likely to be found at the more selective schools. To the extent that the higher graduation rate of those schools does depend on their ability to identify and attract these students, Bowen and Bok's claim that minority students would not be better off at schools where the credentials of other students are similar to their own is weakened. The factors that lead to the admission of these students, rather than others who had comparable SAT scores and college grades, would presumably lead them to have higher graduation rates than the latter at whatever institution they might attend. Since they would, on average, be predicted to have higher grades at the less selective schools, the critics argue, they would be better off at those schools.

The validity of that claim depends, in substantial part, on whether the benefits of graduating from a more selective institution are greater or less than the benefits of graduating with higher grades from one that is less selective, a subject discussed below. ${ }^{29}$ But an undergraduate education is not - or so at least some of us would like to believe - merely a means to such post-graduation ends as admission to graduate school or professional success. The college years are both important in themselves and, hopefully, a time for developing interests and skills whose contributions to an individual's life are not fully captured by such tangible measures. It is of some significance, therefore, that of the black students in Bowen and Bok's sample, approximately $90 \%$ of those who entered college in 1976 and 1989 report that they are "very satisfied" or "somewhat satisfied" with their undergraduate education and that two-thirds of these are "very satisfied." Not surprisingly, the satisfaction level of those who withdrew, either to graduate from an-

28. See supra section I.A.

29. See infra notes 63-66 and accompanying text. 
other school or never to graduate, was considerably lower, but even three-quarters of these students say that they are "very" or "somewhat" satisfied (pp. 424-25).

Significantly, the satisfaction level of the black students who graduated from the institution they originally entered is not correlated with SAT scores. It is, however, positively correlated with school selectivity. At nearly every SAT level, the percentage of black graduates who respond that they are "very satisfied" with their undergraduate education is higher at more selective institutions than at less selective ones (pp. 198-200). Substantial numbers credit their undergraduate education with contributing a "great deal" to the development of academic skills and capacities they regard as "very important" - analytic skills, writing ability, and the ability to work independently. ${ }^{30}$ Significantly, the more selective colleges tended to receive the highest ratings (p. $210 \mathrm{n} .15$ ). These data are an important indication, as Bowen and Bok conclude, that most black graduates of selective institutions do not believe they have been "victimized" by race-sensitive admission policies. ${ }^{31}$ Of course, the high level of satisfaction with their undergraduate education does not prove that black students would not have been even happier and achieved even more if they had attended less selective colleges at which the credentials of other students would have been similar to their own. But it is at least evidence that they have not been "crushed" by the experience, but believe, rather, that they have benefited from it. ${ }^{32}$ For more tangible evidence of whether they suffered by attending more selective institutions, either in their

30. It is, however, rather surprising that only 40 to $50 \%$ credited their colleges with making that much of a contribution to the development of these skills and capacities. P. 212. Since the percentages are equal to or higher than that of white students making that judgment, it would be inappropriate to interpret the black student response as evidence that large numbers of black students believe their education has been adversely affected by attending a college beyond their capacities.

31. See p. 216. Nor, apparently, do those black students who withdrew and did not graduate from any college view themselves as victims of these policies. Black "dropouts" from SEL-1 and SEL-2 schools were more satisfied with their college experience than were white "dropouts." At SEL-3 schools the satisfaction levels were the same. See p. 200. Bowen and Bok do not, however, report the satisfaction levels for this group of matriculants.

Of course, some black students may feel "victimized" in a quite different way, not because they have been put into an academic environment that is inappropriate for them, but because they would have been admitted without the benefit of a minority preference policy. At least some of these students believe that the existence of the policy calls their achievements into question. See generally Stephen L. Carter, Reflections of an Affirmative Action BABY (1991).

32. However, I doubt that any more can be inferred. The complexities of an individual's response to an experience as lengthy and as varied as the college years cannot be captured by a question that asks only whether the individual was "very" or "somewhat" satisfied or dissatisfied with the experience. Prior to matriculation, for example, black C\&B students, on average, rated themselves as average or somewhat above average on their mathematical, scientific, and writing abilities. P. 438. Their subsequent performance in college must, for many, have entailed a significant loss of confidence. 
intellectual development or otherwise, we must turn to their achievements in later life.

\section{Post-Baccalaureate Achievements: Graduate Study}

As in their discussion of college performance, the data Bowen and Bok report about post-college achievements are for all African Americans in the $\mathrm{C} \& \mathrm{~B}$ cohorts studied, not merely those who were admitted in virtue of race-sensitive admission policies. Since a substantial majority of black students were admitted because of such policies, those data tell us something about the consequences of the policies. Nevertheless, it is important to remember that a substantial minority of African-American students would have been admitted under a race-neutral admission policy and that the level of their achievements after college, just as their performance in college, is likely to be higher than that of "specially admitted" students. ${ }^{33}$ Accordingly, Bowen's and Bok's data convey a somewhat misleading impression of the latter's achievements, though just how misleading is indeterminate.

One measure of success in college is the ability to do graduate work. Although many college graduates, for a variety of reasons, decide not to pursue graduate study, advanced degrees have become increasingly common. Just as a high school diploma came to be regarded as insufficient to prepare young people for a growing number of occupations, a college degree, especially in the liberal arts, is now widely thought inadequate to prepare graduates for an ever-larger number of positions. Not surprisingly, C\&B students earned graduate degrees at a markedly higher rate and at a more advanced level than students at other four-year colleges. In the 1976 entering class, the ratio was more than two to one: $51 \%$ for the former and less than $25 \%$ for the latter. The disparity is reduced among graduates - $56 \%$ compared to approximately $37 \%$ - but, as might be expected, there is a significant difference in the level of the degrees earned by $C \& B$ graduates and the graduates of other schools. Less than a third of the advanced degrees received by all college graduates in the relevant age cohort were doctoral or professional (business, law, and medicine) degrees, while approximately $70 \%$ of the advanced degrees earned by the C\&B graduates were at those levels (pp. 96-98).

The comparative data for black and white C\&B graduates is rather more surprising. An identical $56 \%$ of blacks and whites

33. SAT scores "play a substantial role in predicting which undergraduates go on to attain higher degrees even after we take account of interrelationships with high school grades, socioeconomic status, and [undergraduate] school selectivity." P. 107. Similarly, in the 1976 $\mathrm{C} \& \mathrm{~B}$ cohort, the only cohort for which earnings were investigated, "higher SAT scores were quite consistently associated with higher average earnings ...." P. 133. 
earned a graduate degree and a somewhat higher percentage of blacks - $40 \%$ compared to $37 \%$ - earned professional or doctoral degrees. ${ }^{34} \mathrm{~A}$ marked difference exists in the types of degrees earned by members of the two groups. Blacks were substantially less likely than their white classmates to earn $\mathrm{Ph} . \mathrm{Ds}$., but more likely to earn professional degrees. ${ }^{35}$ Strikingly, despite the markedly lower level of their performance in college and on professional school entrance exams, black graduates of C\&B schools were significantly more likely than their white classmates to earn their professional degrees at a small number of institutions Bowen and Bok denominate as "top-tier." 36

Bowen and Bok devote considerable effort to identifying the factors that contribute to the remarkable success of black C\&B graduates in achieving advanced degrees, but though they mention it (pp. 103-15), they give little attention to what is far and away the most important factor: race-sensitive admission policies have been widely adopted by graduate and professional schools. Without such policies, the participation of African Americans in graduate and professional programs, including those who graduated from $C \& B$ schools, would be vastly different from what it was for the classes Bowen and Bok investigated. Data drawn from studies of law school admissions illustrate the point.

A study of law school admissions for the fall of 1976, a year in which African Americans constituted just under 5\% of the applicants admitted to at least one law school, concluded that the percentage would have fallen by a minimum of $60 \%$ if race-neutral admission policies had been employed. ${ }^{37}$ But that projection, which was based upon the improbable assumption that every black applicant would have been willing to attend any law school in the United

34. See p. 98. A different and somewhat more complex picture emerges if black and white matriculants are compared. The percentage of whites and blacks earning professional and doctoral degrees remains very similar (nearly $28 \%$ for whites compared to $26.5 \%$ for blacks), but the percentage of whites earning a master's degree (other than an M.B.A.) is nearly $30 \%$ higher. (Percentages computed by the author from Appendix Tables D.3.3 and D.4.1.)

35. Bowen and Bok note that the percentages of blacks and whites pursuing $\mathrm{Ph} . \mathrm{Ds}$. is nearly identical among C\&B graduates in the 1989 entering class. See pp. 99-100. Unfortunately, they do not report data on the fields of study for either cohort. In 1986, at or near the time that the 1976 entering class might be expected to have earned a doctoral degree, just over half of all doctoral degrees earned by African Americans were in education (in comparison with just under one-quarter for whites). By 1996, the percentages had fallen for both groups, to $44 \%$ for blacks and $20 \%$ for whites. See OfFice OF SCIENTIFIC AND EnGINEERING Personnel, National Research Council, Doctorate Recipients from United States UnIVERsities 40 (1998) [hereinafter Doctorate ReCIPIENTs].

36. See pp. 101-02. The institutions, which are not identified, consist of eight law schools, six business schools, and twelve medical schools. See id.

37. See Franklin R. Evans, Applications and Admissions to ABA Accredited Law Schools: An Analysis of National Data for the Class Entering in the Fall of 1976, 3 L. ScH. Admission REs. 551, 612 (1977). 
States that would admit him, is undoubtedly too optimistic. The availability of financial aid, locational preferences, the reduced return on investment from attending a less prestigious school, and other factors would surely reduce the "yield" markedly, say by $50 \%$. On that assumption, the percentage of African Americans in the 1976 entering class would have been reduced to approximately $1 \%$, roughly the same percentage as existed in $1964 .{ }^{38}$ And these students would have been concentrated in historically black institutions and other of the least selective law schools.

The grim reality is that the most recent data reveal little change in this depressing picture. A study of law school admissions for the academic year 1990-91, employing a model similar to that employed in the 1976 study, concluded that more than half of the black applicants admitted that year would have been denied admission to any law school under a race-neutral policy, reducing the percentage of admitted applicants from $6.8 \%$ of all admissions to just half that number. ${ }^{39}$ Because that model, for reasons discussed in the preceding paragraph, substantially overstates the likely "yield," the 1991 study employed a second model to determine whether black applicants would have been admitted to any of the schools to which they had applied. Projections based on that model reduce the percentage of African Americans admitted still further, to $1.6 \%$ of the total. ${ }^{40}$ Since the second model almost certainly underpredicts the number of blacks who would have been accepted at a school they would have been willing to attend, ${ }^{41}$ the effect of a race-neutral policy probably lies somewhere between the two projections, but closer to the latter than to the former. Nearly all of those who would have been admitted to at least one accredited law school would have been admitted only to an historically black institution or to another of the least selective law schools. Of the 420 black applicants actually admitted to one of the eighteen most selective

38. See Wightman, supra note 4, at 28 (citing Report of Minority Groups Project in ProCEEDINGS of tHe Association OF AMERICAN LaW Schools 112 (1965)).

39. See Wightman, supra note 4, at 29.

40. See id. at 22 tbl.N3.

41. The second model assumes that each law school would admit applicants in rank order of index numbers obtained by combining an applicant's college grades and LSAT score. There are at least two reasons why it understates the number of African Americans who would have attended law school. First, though law schools probably rely on grades and admission test scores more heavily than undergraduate schools, they do consider a variety of other factors, apart from race, in deciding which applicants to admit. Thus, the model predicts that 6,300 of the 44,000 white applicants actually admitted to at least one of the schools to which they applied would have been denied admission. Precisely how these deviations from the model's predictions would have affected black applicants is uncertain, but it seems highly likely that the model similarly underestimates the number who would have received at least one offer of admission. Second, it seems probable that at least some of the applicants who failed to gain admission to any of the schools to which they applied would have been willing to attend another school to which they would have been admitted. 
schools, no more than several dozen would have received an offer of admission under a race-neutral policy. 42

These studies demonstrate the continuing importance of minority preferences if African Americans are to have more than a nominal presence in law schools, especially in those schools from which the profession and the nation draw many of their leaders. But they also demonstrate that, in regard to preparation for graduate education, minority preference programs at the undergraduate level are "successful" mainly in the sense that they enable many black students to gain admission to graduate schools that also have preferential admission policies. To be sure, it is highly probable that C\&B graduates are disproportionately represented among the small group that would have been admitted to a graduate or professional program under race-neutral admission policies. Nevertheless, were such policies in place, many of those who were admitted would not have been admitted to the institutions they attended, or, very likely, to an institution they would have been willing to attend, or, perhaps, to any school. Illustratively, as a rough estimate, approximately sixty to sixty-five black C\&B graduates from the 1989 entering class have attended or will attend one of Bowen and Bok's eight "top-tier" law schools. As noted above, however, under raceneutral admission polices no more than several dozen black applicants would have been admitted to a substantially larger group of schools, many of which are less selective than the "top-tier" institutions. ${ }^{43}$ At least some of these, it should be borne in mind, are likely to be graduates who would have been admitted to their undergraduate schools under a race-neutral policy.

42. See Wightman, supra note 4 , at 30 . The distribution of admission offers explains why the percentage of African Americans attending law school would be closer to the projections based on the second model. The schools to which black applicants would have been admitted lack the financial resources of the more selective schools. Moreover, many black applicants would be unwilling to attend any of the schools to which they would be admitted because the expected return on investment would be significantly less than that they anticipate receiving by attending the schools to which they are now admitted.

43. See supra text accompanying note 38 . The estimate is based on the following calculations and assumptions: Bowen and Bok's data indicate that approximately $7 \%$ of the 32,491 who matriculated at C\&B schools in $1989(2,275)$ were African Americans. See pp. 34, 41, 292 tbl.A.1. Of these, $75 \%(1,706)$ graduated from the institution they originally entered. See p. 56 fig.3.1. Since Bowen and Bok do not report the percentage who attended either any law school or a "top-tier" school, I have assumed that the percentages are the same as those reported for the 1976 class. On that basis, 14 percent of the graduates from the 1989 entering class (239) would be expected to attend some law school, and 26 percent of these (62) would be expected to attend a "top-tier" school. See pp. 100, 102.

To extend the illustration a bit further, under a race-neutral policy the most selective 89 schools of the 171 included in the Wightman study would have admitted not more than 200 to 225 black applicants, somewhat less than the estimate of 239 black C\&B graduates who might be expected to attend law school. See Wightman, supra note 4, at 24,30. (For reasons set out in the text, I have increased Wightman's estimate that only 170 would have been admitted.) Moreover, it does not seem reasonable to assume that all of those admitted would be graduates of $\mathrm{C} \& \mathrm{~B}$ schools. 
Although the overwhelming majority of black students who entered law school in 1991 would not have been admitted under raceneutral policies, approximately $80 \%$ did graduate. Moreover, the graduation rate for those who were "special admits" and those who would have been admitted under race-neutral policies does not differ significantly. ${ }^{44}$ The high graduation rate is frequently cited as evidence that racial preferences do not result in the admission of unqualified students. ${ }^{45}$ The claim is tautologically true if "qualified" means that the students admitted will graduate. As discussed above, however, graduation standards do not exist independently of faculty decisions about the quality of work that should be regarded as minimally acceptable, decisions that are strongly influenced by the quality of work produced by students. ${ }^{46}$ Especially at more selective schools, grades below the minimum necessary for graduation have become exceedingly rare. As discussed below, the presence of a large percentage of "special admits" has played an important role in that development. ${ }^{47}$

Performance on the bar examination may, therefore, be a better measure of whether students admitted to law school because of minority preference policies are "qualified." 48 A study recently published by the Law School Admission Council, based on data from the class that entered law school in 1991, provides the first comprehensive analysis of national bar passage rates. ${ }^{49}$ It found that only $61 \%$ of blacks, as compared to $92 \%$ of whites, passed the exam on their first attempt. ${ }^{50}$ At the law schools C\&B graduates are most likely to have attended, the first-time pass rate for blacks ranged between $64 \%$ and $81 \%$, with a majority likely to have attended a cluster of schools with the higher rate.51 The eventual pass rate is,

44. See Wightman, supra note 4 , at 36 . The graduation rate for whites was approximately $90 \%$, but for the reasons previously considered in connection with undergraduate schools, neither absolute nor comparative attrition rates are very useful measures of the qualifications of matriculants. See supra section I.B.

45. See, e.g., Wightman, supra note 4 , at 36.

46. See supra section I.B.

47. See infra text accompanying notes 69-70.

48. At a minimum, bar examiners do not necessarily have the same commitments as the law faculties responsible for the adoption of those policies.

49. See Linda F. Wightman, LSAC National Longitudinal Bar Passage Study 2 (L. Sch. Admission Council Res. Rep. Series 1998).

50. See id. at 27 tbl.6.

51. See id. at 28 tbl.7. Wightman divides accredited law schools into six "clusters" with decreasing mean LSAT scores. The assumption in the text is that C\&B graduates are highly likely to have attended a school in the top three clusters. See id. Moreover, since onequarter of the black C\&B graduates from the 1976 cohort who graduated law school attended a "top-tier" law school, a much smaller and more selective group of schools than those included in Wightman's most selective group, it seems very likely that a majority or more of the C\&B graduates in Wightman's study attended a law school whose black graduates had an $81 \%$ first-time passing rate. See p. 102 fig.4.4. 
of course, somewhat higher. The cumulative percentage of blacks that pass on the second or subsequent attempt rises to $78 \%$, compared with $97 \%$ for whites. 52 The rate for those who graduated from the group of law schools $\mathrm{C} \& \mathrm{~B}$ graduates are most likely to have attended ranges from 79 to $94 \%$, again with most coming from a cluster of schools with the higher of these rates..$^{53}$

These data suggest a number of conclusions. The failure of over a fifth of black law school graduates who sought entry into the profession ever to pass the bar is compelling evidence that many law schools are not merely admitting, but graduating, a large number of students who lack even the minimal competence necessary to pass a bar examination. A judgment about whether any justification exists for this waste of individual and institutional resources, and for the psychic toll it exacts from the unsuccessful students, depends upon whether those students can be identified either at the time of the admission decision or thereafter. If they can, it seems not merely imprudent, but unconscionable, not to do so. If they cannot, however, faculties ought in good conscience to begin confronting the question whether the costs of admitting and graduating these students is justified by the increase in the number of black lawyers that results from their minority preference policies. ${ }^{54}$

Though law schools are admitting and graduating a significant number of African-American students who will never become lawyers, it no less true that race-sensitive admission policies do result in a major increase in the number who are admitted to the bar. As discussed above, as many as $70 \%$ of the blacks entering law school in 1991 would not have done so if race-neutral admission policies had been in effect. Many of these are surely among the group that never passed the bar, but it must also be true that a larger percentage is among the group that did. Perhaps inevitably, proponents and critics of minority preference policies have differing views about the competence of even the latter and, therefore, about the importance and desirability of the policies. Linda Wightman, the author of both the admission and bar passage studies, appears to regard the eventual pass rate as the appropriate measure of competence. She concludes, therefore, that the policies are successful in bringing to the bar a large number of competent African Americans (and other minorities) who would not otherwise have

52. See Wightman, supra note 49 , at 32 tbl.10.

53. See id. at 33 tbl.11.

54. The question need not be whether the policies should be abandoned because of these costs. In view of the relatively high correlation between LSAT scores and both law school grades and bar passage, see id. at 37-39, it may well be possible to identify a group of applicants whose chances of passing the bar are sufficiently slim that they should not be admitted, or who should be flunked out at the end of their first year, even though some would eventually pass the bar. 
gained entry to the profession. 55 Stephan Thernstrom, a prominent critic of race-sensitive policies, takes a quite different view. Emphasizing that the exam offers only a test of whether an applicant for admission to the bar has the minimum intellectual competence to practice law, he wonders whether those who have achieved a passing grade only on a second or subsequent attempt can be thought to have a "firm . . . command of the law." It is, he argues by way of analogy, reasonable to be uneasy about driving in a car with someone who has passed a driver's test only after multiple attempts. .56

The disagreement between Wightman and Thernstrom poses difficult questions for law faculties and bar examiners, but they almost certainly have considerably less direct significance for C\&B schools. Whatever doubts one may have about the intellectual ability of bar applicants who have performed poorly in law school and have passed the bar exam only after two or three attempts, those who pass on the first attempt have at least demonstrated a level of competence equal to that established for entry into the profession. It is highly probable that a substantial majority of black C\&B graduates who sat for the exam did pass on their first try. Wightman's data reveal that $88 \%$ of the African Americans who sat for the bar and had an LSAT score above the overall national mean passed on their first try. Since the mean SAT scores of black C\&B matriculants in the 1989 cohort were well above the seventy-fifth percentile (pp. 18-19, 29), and since SAT and LSAT scores are positively correlated, it is reasonable to suppose that $C \& B$ graduates going to law school may generally score above the mean on the LSAT, even given the more academically selective group who take the later test.

To the extent that the experience of law schools is at least roughly comparable to that of other professional and graduate fields of study, it seems fair to conclude, as Bowen and Bok do, that African-American graduates of selective colleges who go on to earn advanced degrees "are the backbone of the emergent black ... middle class" (p. 116). It is less clear, however, just how much the racesensitive admission policies of those institutions contribute to that end. Although it is true that a substantial majority of AfricanAmerican matriculants at those institutions would not have been admitted under race-neutral policies, neither Bowen and Bok's data nor any other of which I am aware permit an informed judgment

55. See id. at 80.

56. See Stephan Thernstrom, Diversity and Meritocracy in Legal Education: A Critical Evaluation of Linda F. Wightman's "The Threat to Diversity in Legal Education," 15 CoNST. Comm. 11, 32-33 (1998). Every lawyer knows of at least one law student who did quite well, perhaps brilliantly, in school and yet failed the bar exam on his first attempt. Thernstrom's argument is made against a very different background, with reference to a group of students who performed quite poorly in law school. See id. at 26. 
about the extent to which undergraduate "special admits" are among the group that achieve professional status or how many of those who do would have achieved such status even if they had attended an undergraduate school to which they would have been admitted under a race-neutral policy.

Consider first the considerable number of obstacles that must be overcome between matriculation and the achievement of professional status. Twenty to $25 \%$ of all African Americans who matriculate at C\&B schools do not graduate (p. 56 fig.3.1). Over $40 \%$ of the graduates will not attend a graduate or professional school ( $\mathrm{p}$. 98 fig.4.2). Of those who do, the experience of the law schools suggests that even though the attrition rate for $C \& B$ graduates is likely to be lower than the national rate, a nonnegligible number will not graduate. ${ }^{57}$ And finally, to build on the law school experience once again, a nonnegligible number, even of $C \& B$ graduates, will fail to pass a professional licensing exam or to achieve an equivalent level of competence in fields that do not impose such a requirement. Since predictors of academic success are correlated with success in surmounting each of these hurdles, it is likely that "specially admitted" students are disproportionately included among those who fail to do so.

In addition, even though some of the "specially admitted" C\&B students undoubtedly did go on to attain professional status, it is uncertain how many of those who did would have done so had they attended an undergraduate school to which they would have been admitted under a race-neutral policy. Many of those "specially admitted" were admitted because, despite their relatively low SAT scores, they had other characteristics that persuaded admission officers they were likely candidates for eventual success. Just those characteristics, however, are likely to have enhanced their prospects for achieving professional status even if they had attended less selective schools. It is surely a plausible hypothesis, one not refuted by Bowen and Bok's data, that their chances for achieving that status would have been markedly greater than those of students with comparable SAT scores - but not other relevant characteristics who attended those institutions.

It would be premature to conclude that race-sensitive policies in undergraduate schools do not play an important role in the production of black professionals. My only point is that, despite the voluminous data gathered by Bowen and Bok, the question of how important they are remains open. ${ }^{58}$

57. See Wightman, supra note 4 , at 36.

58. Bowen and Bok do at one point attempt to estimate the number of C\&B AfricanAmerican "special admits" in the 1989 entering class who were pursuing a medical degree, concluding that they represented over half ( 80 out of 152) of all black matriculants seeking such a degree. See pp. 359-61. The estimate is flawed because, as discussed in the text, the 


\section{Post-Baccalaureate Achievements: Work}

Whatever doubts may exist about the significance of collegelevel minority preference policies in increasing the number of black professionals, Bowen and Bok's data impressively demonstrate the importance of those policies in augmenting the representation of blacks in the upper reaches of the middle class. African Americans who attend selective undergraduate schools, including those who gain admission because of those policies, have high incomes. The evidence strongly indicates that they do so because of their attendance at those schools. ${ }^{59}$

The average annual earnings in 1995 of graduates who entered college in 1976 is set out in the following table: ${ }^{00}$

$\begin{array}{lcc}\begin{array}{l}\text { C\&B colleges } \\ \text { (white) }\end{array} & \text { Men } & \text { Women } \\ \begin{array}{l}\text { C\&B colleges } \\ \text { (black) }\end{array} & \$ 101,900 & \$ 66,000 \\ \begin{array}{l}\text { All institutions } \\ \text { (white) }\end{array} & 85,000 & 64,700 \\ \begin{array}{l}\text { All institutions } \\ \text { (black) }\end{array} & 63,100 & 42,600 \\ & 46,800 & 37,500\end{array}$

As the table reveals, black $C \& B$ graduates earned less than their white classmates, ${ }^{61}$ markedly so in the case of men, but they earned

number of medical students who are $\mathrm{C} \& \mathrm{~B}$ graduates is too small to permit a judgment about the extent, if any, to which undergraduate "special admits" are included among them. In addition, it is unknowable just how many of these young people would have attended medical school had they attended an undergraduate school to which they would have gained admission under a race-neutral policy.

It should be apparent that similar doubts about the importance of race-sensitive admission policies in professional schools are not justified. A great deal of the uncertainty about the extent to which such policies in undergraduate institutions contribute to the production of black professionals is attributable to the fact that less than half of African-American matriculants at C\&B schools go on to graduate study. It is, therefore, uncertain how many of those who do were admitted to their undergraduate schools because of minority preference policies. As the law school data demonstrate, however, race-sensitive admission policies are responsible for a large majority of African-American admissions to professional schools. Even if those students are disproportionately represented among the admittees who ultimately fail to achieve professional status, a large number of those who do must be among the group that was "specially admitted." Moreover, since the law school data concern all accredited institutions, there are not, as there are at the college level, other institutions that might have been attended by those "special admits" who would have been denied admission under race-neutral policies.

59. Because of the many variables that affect the income data collected by Bowen and Bok - e.g., differences in gender and occupational distributions in the different populations they examine - their analysis is quite complex. Within the confines of this review, I can only summarize and explore the implications of the most important findings.

60. P. 124 fig.5.2. The averages include only the earnings of individuals employed fulltime and full-year.

61. Although not central to the issues considered in this review, a brief comment on the black-white earnings gap is appropriate. Once controls are added to take account of SAT scores, college grades, family socioeconomic status, differences in fields of study, and other correlates of earnings, differences between the earnings of white and black women disappear. 
considerably more than both black and white graduates of all fouryear colleges. Moreover, the earnings advantage gained by attending a selective institution was, in percentage terms, markedly greater for blacks than it was for whites.

The initial question suggested by these data is whether the earnings advantage enjoyed by black $C \& B$ graduates was attributable to their having attended a selective college or to the qualities that led to their admission to such an institution. On average, after all, black matriculants at those schools did have admission credentials superior to those of both black and white matriculants at other schools (pp. 18-19). Nevertheless, Bowen and Bok seem clearly justified in concluding that there is "a real wage premium associated with enrollment at an academically selective institution" (p. 128). As they note, several prior studies, after controlling for precollege differences in student ability, reached just that conclusion. Bowen and Bok's data offer additional support. Initially, they compared the earnings of white male $C \& B$ matriculants with the earnings of white male matriculants at all four-year colleges and, separately, with the earnings of a smaller group of white male matriculants at those institutions who, because of their academic achievements, are assumed to have had roughly comparable abilities with the $\mathrm{C} \& \mathrm{~B}$ cohort. These comparisons lead them to conclude, as a rough estimate, that only one-quarter of the earnings gap between the white male C\&B matriculants and all white male matriculants is attributable to student quality (p. 127). A similar conclusion is suggested by their finding that, among graduates of $C \& B$ schools, earnings "correlate very strongly with the selectivity of the school attended" (p. 138). The differences are significant at each level of selectivity, and they exist for women, men, blacks, and whites (p. 139 fig.5.6). Moreover, they are "essentially unaffected when controls of all

See p. 145 . For men, however, these controls eliminate only $60 \%$ of the difference, so that white income continues to exceed that of blacks by $10 \%$. See id. Remarkably, Ronald Dworkin (and, therefore, I suspect others as well) leaps to the conclusion that this "sad fact is alone enough to refute any suggestion that racism has disappeared from our economy." Ronald Dworkin, Affirming Affirmative Action, N.Y. REv. Books, Oct. 22, 1998, at 91, 95 (reviewing THE SHAPE OF THE RIVER).

Bowen and Bok are, appropriately, considerably more cautious. See pp. 144-48. As they recognize, discrimination is a possible explanation, but others are no less plausible. See id. Some or all of the earnings gap might, for example, be attributable to the same kind of "underperformance" observed in college. See supra note 26. Other explanations may also exist. Illustratively, a survey of members of the 1976 entering class who were employed fulltime revealed that, on average, African Americans were more interested than whites in flexible work schedules, low stress in their jobs, and a pleasant work environment. At the same time, they were somewhat less interested than whites in having a high level of responsibility. See p. 152 tbl.5.2. These are entirely sensible choices about how to live, but they are not generally associated with high incomes. Of course, the direction of the causal arrow is uncertain. Still, the data at least suggest the need for further investigation, not facile conclusions. 
kinds [e.g., SAT scores and socioeconomic status] ${ }^{62}$ are introduced."63

One reason that graduates of selective undergraduate institutions enjoy a wage premium over the graduates of other colleges is the large difference between the two in attaining advanced degrees, especially from professional schools. ${ }^{64}$ Thus, even among graduates of C\&B schools, the average earnings of business, law, and medical school graduates range between $\$ 20,000$ and $\$ 69,000$ higher than the earnings of those who earned only B.As. (p. 136 n.27). Since it is uncertain whether, or the extent to which, minority preferences contribute to the production of black professionals, ${ }^{65}$ a question arises whether the earnings premium of black $C \& B$ graduates is attributable to the high earnings of professionals who would have been admitted to their undergraduate schools under race-neutral criteria. The apparent answer is that they are not. Bowen and Bok found that the earnings premium enjoyed by black matriculants at $\mathrm{C} \& \mathrm{~B}$ schools continues even after controlling for advanced degrees. In addition, although pre-college predictors of academic success are associated with higher earnings, the continued significance of attending a selective school, even after controlling for those factors, strongly suggests that "special admits" are among the beneficiaries of the premium. Thus, even those blacks who graduate in the bottom third of their classes earn appreciably more than either the black or white graduates of other institutions (pp. 124, 140-42).

The remaining question is whether, despite the premium, "specially admitted" students would have been still better off financially had they attended a college where, because their admission credentials would have been comparable to those of other students, they might have expected higher grades. ${ }^{66}$ Although college grades are positively correlated with subsequent earnings, and strongly so (pp. 140-42), Bowen and Bok's data are persuasive that black students do not pay a financial penalty for attending a selective institution. The earnings of black C\&B matriculants with comparable SAT

62. For both blacks and whites, each of these is significantly correlated with earnings. See pp. 133-38.

63. P. 140. Precisely why attendance at a selective school confers so great an advantage is uncertain. Very likely, as Bowen and Bok suggest, the reasons are various. Those schools may, because of their greater resources and because of the quality of their students and faculties, provide a superior education. The environment may stimulate ambition and afford a greater knowledge of opportunities. Friendships are established that may provide useful contacts in later life. The prestige of the institutions may simply "rub off" on their graduates. See id. Whatever the reason, the consequence should not come as a surprise. It is a major reason that both parents and high school students are so eager for the latter to gain entry to selective institution and why so many are bitter when they do not.

64. See supra text accompanying notes 33-34.

65. See supra section I.C.

66. See supra section I.B. 
scores decline significantly with each level of school selectivity (p. 144). Although that finding does not eliminate the possibility that they would have done as well had they earned higher grades at a less selective institution, it does justify Bowen and Bok's conclusion that the students did not pay a penalty for attending a more selective institution. As they maintain, while there may have been differences among students with similar test scores that affected their varying degrees of success in the marketplace, "the admissions processes seem to have gauged these differences well" (p. 144).

\section{The ShoAls in the River}

The discussion thus far has considered race-sensitive admission policies mainly from the perspective of those African-American students who are their immediate beneficiaries. In the remainder of this review, I want to consider briefly a number of the issues bearing on the wisdom of such policies from a societal perspective.

\section{A. The Effect on Academic Institutions}

In public statements, academic administrators have at times attempted to minimize the extent of the preference accorded minorities under race-sensitive admission policies, suggesting that race serves only as a tie-breaker or, at most, to overcome small differences among candidates. ${ }^{67}$ These statements are - how should it be put? - disingenuous. As the data discussed above reveal, the academic credentials and subsequent academic performance of African-American students admitted to selective institutions because of minority preference policies are, on average, dramatically lower than those of their white classmates. ${ }^{68}$ Those facts have had an important influence on academic standards. Both institutional and professorial standards for determining the level of work that should be regarded as minimally competent are inevitably influenced by the quality of work produced by students. The presence of "specially admitted" students has affected those standards not only for that reason, but for others that are particularly related to minority admission programs.

As noted above, faculty members at selective institutions have been highly resistant to awarding grades that might cause students to "flunk out."69 Knowledge that a large percentage of those who would be put on the "home list" would be African Americans and,

67. See, e.g., the statements quoted in Thernstrom, supra note 56, at 19-22.

68. See supra sections I.A-B.

69. See supra section I.B. The unwillingness to award such grades may be reflected either in the grades awarded by individual faculty members or in a collective decision by the faculty regarding "grading curves" or other mechanisms designed to minimize or, perhaps, eliminate the possibility of a student receiving grades below the level necessary to graduate. 
indeed, that a substantial percentage of African Americans would be among those "home listed" has undoubtedly been an important factor in that reluctance. "Liberal guilt" is one reason. Another is the fear that a high failure rate would adversely affect an institution's competitive position in the intense competition to attract the most promising African-American students. ${ }^{70}$ But other, more justifiable reasons have also played a role. Many faculty members believe that it would be ethically problematic to admit students who predictably will do less well than their classmates, inviting them to invest a year or more of their lives and perhaps substantial sums, and then fail them out of school. Moreover, a high attrition rate would threaten attainment of whatever institutional objectives have led to the adoption of racially preferential admission policies.

Whatever the reasons, the reluctance of faculties to award grades that would lead to academic dismissals or to voluntary decisions to withdraw because of discouragement has necessarily had an effect on decisions about the quality of work that is to be regarded as minimally acceptable. Once made, those decisions "benefit" all students, not just those who are African Americans. The consequence is not only that schools are graduating students of all races and ethnic groups who might well not graduate without the felt pressure to graduate minority students, but also to exert upward pressure on all grades. "Grade inflation" is not, of course, solely attributable to minority admission policies, but they are surely one of the factors that have contributed to it. The overall effect is a lowering of academic standards, not necessarily from those of some "golden age" that very likely never existed, but from those that might reasonably be expected currently at the nation's premier academic institutions. ${ }^{71}$

Altered grading practices are not the only way in which minority admission programs have compromised academic standards. Some

70. One measure of the intensity of the competition is that black applicants receive more offers of admission than "comparable" white applicants. See pp. 33-34.

71. Bowen and Bok observe that at four C\&B schools the "average SAT score for black matriculants in 1989 was slightly higher than the average SAT score for all matriculants in 1951." They conclude, remarkably, that the "alumni/ae of the 1950 s should have no reason to question the qualifications of the black students of today!" P. 30. Leaving to one side the question whether SAT scores four decades apart are comparable, the question that has been raised and which they purport to address does not involve the qualifications of black students generally, but only of those admitted because of race-sensitive admission policies. The latter group, of course, has a lower score than that of black students generally. See supra section I.A. Moreover, and more relevant to the question whether those policies have a corrosive effect on intellectual standards, grades below the average necessary to remain in good academic standing were surely more common in the early 1950s than they are today.

In any event, the question that needs to be confronted is not whether academic standards have deteriorated from a time when the circumstances of selective institutions were vastly different from those that exist currently, but the effect of minority preference policies on those standards at the present time. 
years ago, while still president of Harvard, Professor Bok argued against minority preferences in faculty appointments. ${ }^{72}$ Although he recognized that many of the arguments for race-sensitive admission policies also apply to hiring and tenure decisions, he maintained that the different roles of faculty and students justify different policies for admissions and appointments. Whatever the merits of that claim, race-sensitive appointment policies are, and have been for a generation, pervasive in colleges and universities. ${ }^{73}$ The consequence is the appointment and promotion of minority group members who lack the academic promise of competing candidates and who, but for their race or ethnicity, would not satisfy institutional standards. ${ }^{74}$ Minority admission policies are not, of course, the only reason that institutions have adopted such policies for the hiring and promotion of faculty, but they have been an important contributing factor. Acceptance of the arguments for the former adds force to similar arguments made for the latter. In addition, the increased number of minority students attributable to the admission policies increases the felt need for, and the political pressure to appoint, more minority faculty than would be hired under race-neutral policies.

The sacrifice of academic standards to achieve greater minority representation within faculties imposes costs that are no less real for being intangible and immeasurable. The intellectual capacity of an institution's faculty is central to its intellectual life. It is the primary determinant of the quality of the faculty's scholarship and research and of the quality of the education it offers its students. The decision to appoint and promote faculty for reasons other than academic excellence thus compromises what are, or ought to be, a university's central commitments. As then-President Bok wrote some years ago:

72. See Derek Bok, Beyond the IVORY TOWER 110-15 (1983).

73. The underlying problem, for faculty appointments as for student admissions, is the desperate shortage of African Americans who satisfy otherwise applicable institutional standards. In many disciplines, the effort to hire what might be regarded as even a minimally acceptable number of African Americans is hampered, at times made impossible, by the fact that the number of blacks earning Ph.Ds. is negligible and at times even lower. See DoctorATE RECIPIENTS, supra note 35, at 68-71. In others, such as law, the number who possess the necessary degree may be sufficient, but only a very few of these have a record of academic achievement that would lead to an appointment or promotion were race not a factor in the decision.

74. Of course, some of the minority group members appointed during this period would have been hired under race-neutral policies. And of those who were appointed because of race-sensitive policies, some have gone on to do work that is quite as creditable as the work of their white colleagues. The same would undoubtedly have been true of some of the white candidates who failed to gain appointment. The faculty's ability to predict the future success of candidates is by no means perfect, which is not to say, as some critics of traditional hiring practices at times appear to argue, that the effort should be abandoned. 
If selection committees decide to pass over the ablest candidates in order to appoint a minority scholar, they can scarcely be said to be furthering the primary educational aims of the institution. On the contrary, they will generally be acting with a clear probability of diminishing the quality of teaching and research. ${ }^{75}$

Perhaps compensating benefits adequate to justify preferential appointment policies exist, but even if they do, it needs to be recognized that those benefits come at a price.

Within colleges and universities, the impact of race-sensitive admission policies on academic standards is seldom, if ever, discussed. Attention has been focused on the educational benefits of racial diversity. Not surprisingly, therefore, Bowen and Bok maintain that most college and university leaders adopted, and presumably have maintained, race-sensitive admission policies mainly because "they sought to enrich the education of all their students by including race as another element in assembling a diverse student body" (p. 7). Whether or not that initially was - or, indeed, is now - the primary motivation may be doubted, but the importance of racial diversity in the educational process has become something of a mantra in higher education circles in the years since Justice Powell's pivotal opinion in Bakke. Powell, it will be recalled, regarded such diversity as the sole permissible justification for taking race into account in college and university admissions. ${ }^{76}$

The importance of diversity to intellectual development is a familiar theme. At its best, higher education is an exploration of the unfamiliar. Exposure to other times and places opens the possibility of new ideas or a deeper understanding of ideas long held. Knowledge that others have lived and thought differently than oneself may reduce parochialism and assist in cultivating that capaciousness of mind characteristic of educated women and men. Engagement with authors, faculty members, and fellow students with differing ideas and experiences offers similar opportunities. Bowen and Bok's data do not, however, speak to the effect of racial diversity on the intellectual development of students. What they do report is that large majorities of both black and white C\&B matriculants in the 1976 and 1989 entering classes say that the "[a]bility to work effectively and get along well with people of different races/ cultures" is "very important" (p. 224 tbl.8.1). Approximately half of each group in the 1976 class and roughly two-thirds of each group in the 1989 class thought that their college experiences had significantly contributed to their development of these abilities (pp.

75. BoK, supra note 72 , at 111.

76. See Regents of the Univ. of Cal. v. Bakke, 438 U.S. 265, 311-14 (1978) (finding, among the four rationales offered by the Regents, only diversity to be acceptable). 
225-29). Accepting these responses at face value, ${ }^{77}$ the increased ability of $\mathrm{C} \& \mathrm{~B}$ graduates to get along with people of other races must be counted as an achievement of race-sensitive admission policies. Many C\&B graduates hold, or are destined to hold, important positions of leadership. Their ability to work effectively across racial lines is vital to the long-term health of the society. Yet, without race-sensitive admission policies the opportunities for developing that ability would be significantly reduced.

Although enhancement of such "socialization skills" is one aim of an undergraduate education, the central educational objective of colleges and universities is the intellectual development of their students. Racial diversity can contribute to that end, but only to a limited extent. The continuing importance of race in American life may make it likely that members of different racial and ethnic groups will have differing experiences and perspectives, but these differences are simply irrelevant to most of what students study in the course of their undergraduate careers. The irrelevance of those differences is perhaps most obvious in the study of mathematics and the natural sciences, but it is no less true of most of the humanities and the social sciences. ${ }^{78}$ Within the latter areas of study, to be sure, issues do arise with respect to which the differing experiences and perspectives of the members of different racial and ethnic groups are relevant. But even with respect to such issues the contribution of racial and ethnic diversity to student learning may be quite limited.

Students learn from one another in different ways. In the course of discussion, whether in the classroom or in dormitory "bull sessions," participants are likely to be exposed to unfamiliar ideas. My own experience and that of colleagues with whom I have discussed the question, experience that concededly is limited to the classroom setting, is that racial diversity is not responsible for generating ideas unfamiliar to some members of the class. Students do, of course, quite frequently express and develop ideas that others in the class have not previously encountered, but even though the subjects I teach deal extensively with racial issues, I cannot recall an instance in which, for example, ideas were expressed by a black student that have not also been expressed by white students. Black

77. Bowen and Bok acknowledge that there may be reasons to doubt that the responses should be taken at face value. "[D]isentangling cause and effect is extremely difficult: students most predisposed to benefit from diversity are most likely to report its beneficial effects, and positive attitudes toward diversity may well color perceptions of what was gained from the college experience." P. 219.

78. See BoK, supra note 72, at 112 ("Even the most avid proponent of diversity would be hard put to argue that the special perspective of a minority scholar will contribute much to teaching and research in the natural sciences or in classics, English literature, logic, or many other important fields of study."). 
students do, at times, call attention to the racial implications of issues that are not facially concerned with race, but white and AsianAmerican students are in my experience no less likely to do so.

The contribution of racial diversity to student learning lies elsewhere. At times, the importance of what is said depends less upon the idea expressed than upon the identity of the speaker and the manner of expression. Experiences recounted by a friend may help to deepen understanding of bloodless accounts in a newspaper, a sociology text, or a judicial opinion. Illustrations abound. It is, for example, one thing for Asian Americans or whites to read that store employees often subject African Americans to surveillance and quite another to have black friends who have had that experience and to hear their reactions to it. Engagement with whites and Asian Americans who oppose minority preferences may assist black and Latino students to appreciate, as the printed page may not, that those views are not necessarily rooted in racial or ethnic animus. Acquaintance with individuals from other racial and ethnic backgrounds may help students to comprehend, more than many now do, that other racial and ethnic groups are not monolithic and that among their members one may find widely differing backgrounds, perspectives, and needs. The knowledge that comes from such experiences is important not only in enabling students to work effectively with others, but in deepening their understanding of American society and, perhaps, in evaluating public policies that may come before them as citizens and future leaders.

Although racial and ethnic diversity in the student body may, thus, make a useful contribution to the education of students, the extent of the contribution needs to be kept in perspective. Contact with students of other races may enrich the educational experience, but it can hardly be regarded, as the most ardent advocates of racesensitive admission policies at times appear to do, as an indispensable element of an undergraduate education. Even the development of a capacity for empathic understanding of ideas and experiences different from one's own, which I take to be the primary contribution of racial diversity to the intellectual development of students, does not depend upon it. To appreciate that racial diversity may enrich education, but is not indispensable to it, is to open the way for balancing the costs and benefits of programs necessary to achieve it. ${ }^{79}$ Reasonable people of good will may differ about whether the educational benefits of racial diversity are sufficient to compensate for the effects of minority preference policies on the

79. The same is true of decisions made at the individual level. Students who attend such institutions as Fiske and Morehouse are denied educational opportunities available at racially diverse institutions, but the benefits may, in particular cases, more than compensate for what has been lost. 
maintenance of academic standards, but the question is one that deserves more attention than it has received from institutions that have such policies.

\section{B. Strengthening the Black Middle Class}

One important consequence of race-sensitive admission policies is a significant increase in the average earnings of those African Americans who are their immediate beneficiaries. ${ }^{80}$ Policies that contribute to increasing the number of African Americans with relatively high incomes are surely desirable, but if they achieve no more, it is not evident that they are any more desirable than policies that would raise the incomes of any other individuals, say, the Asian-American and white students displaced by race-sensitive admission policies. The justification for policies that aim to enlarge the size of the black upper-middle class is not to increase the incomes of the individuals who are their immediate beneficiaries, but to produce a larger social benefit. Work is one important sphere within which one might hope for such benefits. The argument has often been made - I have made it myself - that important social benefits can be expected to result both from increasing the participation of blacks in all the work settings in which higher education is required and in assuring that they have the best education available for those positions. ${ }^{81}$ It is not a criticism of Bowen and Bok's study that they did not investigate whether these hopes have been realized. A single study can undertake only so much, but after three decades we need to know a good deal more than we now do about the job performance of the immediate beneficiaries of minority preference policies.

One question is how well the ordinary tasks associated with the positions are being performed. It may be, as Bowen and Bok suggest, that the positions held and incomes earned by "specially admitted" students are evidence that they are performing creditably in those positions (p. 117). But though the pressures are perhaps less intense than they are for academic institutions, employers are also subject to internal and external pressures to increase their minority representation. "Market tests" are, therefore, not necessarily as probative of competence as Bowen and Bok assume. In any event, to the extent that "market tests" are regarded as probative, the evidence is ambiguous. Black college graduates, including graduates of $\mathrm{C} \& \mathrm{~B}$ schools, have significantly lower earnings than their white classmates. ${ }^{82}$ The differential may, as many assume, be attributable to continued discrimination in the relevant job mar-

80. See supra section I.D.

81. See Sandalow, supra note 8 , at $688-89$.

82. See supra text accompanying note 60 . 
kets, but it may also be attributable, in whole or in part, to differences in competence. ${ }^{83}$

A second question, no less important, is whether increased minority representation in the positions held by graduates of selective colleges has brought the distinctive benefits that were anticipated from a minority presence. As I put it nearly a quarter-century ago, "[a] black presence [in various influential institutions] is likely to alter the behavior of these institutions in a host of subtle and perhaps not so subtle ways, making them more responsive to the varying needs of the black community." 84 In assessing minority preferences, it would be relevant to know whether African Americans have in fact brought different experiences and perspectives to their jobs and whether institutional behavior has been affected by their presence. Yet another question is whether, or the extent to which, there has been a diffusion of benefits conferred upon the immediate beneficiaries of preferential policies. One facet of that question is whether there is any evidence to support the "role model" theory that has played so important a part in the arguments for race-sensitive policies. Another, quite different, is the extent to which the relatively high incomes enjoyed by the beneficiaries of those policies have led to support for institutions that seek to improve the conditions of life for African Americans generally.

Bowen and Bok do direct attention to one aspect of this latter question: the extent to which black graduates of $\mathrm{C} \& \mathrm{~B}$ institutions are participants in civic activities. Nearly $90 \%$ of African Americans who entered those schools in 1976 reported that during 1995 they had engaged in one or more civic activities and many of these held leadership positions (pp. 156-62). Because of the high participation rate, a large number of those who did participate must have been admitted because of minority preference policies. And since SAT scores are not correlated with leadership positions ( $\mathrm{p}$. 165), it seems reasonable to assume that many who did hold such positions were also "special admits." It would be inappropriate to conclude, however, that attendance at selective schools was responsible for the high rate of either participation or leadership. High school activities that predict participation and leadership in civic activities are an important factor in deciding which applicants to admit, especially in selecting among those applicants who have relatively weak academic credentials. It is entirely predictable, therefore, that African-American students at those institutions will, in their later lives, be actively involved in civic organizations. The importance of attending a selective college lies elsewhere, not in

83. See supra note 61.

84. Sandalow, supra note 8 , at 688 . 
leading students to engage in civic activities, but in enhancing the quality of their efforts. To be sure, the belief that attending those institutions will enhance the quality of their efforts depends upon two assumptions, that education is relevant to effective participation and leadership and that the education received at a selective college is likely to be superior to that obtained at other institutions. Those are, I suspect, assumptions most readers will be willing to make.

Although the evidence is not entirely unambiguous, the high levels of civic participation appear to justify Bowen and Bok's conclusion that $C \& B$ graduates, and especially those with advanced professional degrees, "are giving back and maintaining ties to their communities, while also forging links with the broader American society." 85 To be sure, among C\&B graduates more blacks (and whites) participate in professional activities than in any other type of activity. Nevertheless, many also report that they participate in community, social service, youth, educational, and religious activities. In view of the persisting high levels of de facto racial segregation throughout American life, it seems fair to conclude, as Bowen and Bok write, that $C \& B$ graduates are engaged in activities that help "to strengthen the social fabric of the black community" (p. 169). The data do not, however, fully address the concerns expressed by William Julius Wilson and other prominent black scholars about whether those blacks who have benefited from the opportunities that have opened up during the past thirty years are providing leadership that will help to improve the conditions of life among blacks generally (pp. 169-71). What the data do not reveal is whether the active community involvement reported by $C \& B$ graduates is concentrated in organizations whose activities primarily affect other relatively privileged African Americans or whether they also participate in activities that benefit the larger number of blacks who are among the "truly disadvantaged" 86 or who are, at least, significantly less advantaged. No doubt, even the former, insofar as it assists in stabilizing and perpetuating an enlarged black middle class, should count as a social gain, but it is somewhat less of one than hoped for by many advocates of minority preference. Of course, the data also leave open the possibility that the civic activities of the C\&B graduates are directed, to a substantial extent, to others less fortunate than themselves.

85. P. 171 (emphasis in original). It is worth noting that blacks who matriculated at other colleges report a higher rate of participation in nearly all of the community-centered activities. The only area of activity in which $C \& B$ graduates participate at a significantly higher rate is "professional."

86. The phrase is, of course, William Julius Wilson's. See William Julius Wilson, The Truly Disadvantaged: The Inner City, The Underclass, and Public Policy (1987). 


\section{Social Stability and Social Values}

In Bakke, Justice Powell dismissed, without discussion, the idea that "[p]referring members of any one group for no reason other than [their] race or ethnic origin" might be a legitimate social objective. ${ }^{87}$ The casual dismissal of that objective led Powell to ignore what may be the most important justification for race-sensitive admission policies and, more generally, for minority preferences in employment and perhaps other areas in which they exist.

Absent race-sensitive admission policies, as detailed above, the representation of African Americans at selective colleges and universities would be dramatically reduced. At the most prestigious of those institutions, their numbers would be negligible. Even at less selective schools - say, the flagship universities of state systems of higher education - black enrollment would be unlikely to rise above several percent. At some point, there is a need to confront the question whether such a result would be socially or politically tolerable. Especially during the past decades, selective undergraduate schools have come to serve as important gateways to positions of wealth, power, and prestige. A drastic reduction in the number of blacks represented in these institutions would severely curtail the opportunities for African Americans to move into such positions. The importance of maintaining a reasonable representation of blacks in the student body is not merely instrumental, however. Selective undergraduate schools are themselves important social territory. Attendance at and graduation from them confer status in contemporary American society. To deny blacks reasonable representation in these institutions, effectively even though not formally, is for these reasons to deny them access to an important social good. This denial may itself have significant social consequences.

Politicians have long recognized the importance of including representatives of major social groups in the ranks of officialdom. In cities such as New York and Chicago, for example, political parties typically presented a "balanced ticket" to the voters, that is, one that included a representative of each of the major ethnic groups in the population. A cynic might view the practice as no more than an effort to garner votes, but the justification for it runs deeper. The inclusion on the ticket of a fellow ethnic was understood by many new citizens as a token that the group with which they identified was valued. It was not only the members of ethnic groups to whom politicians sought to convey that understanding. At a time when regional divisions within the United States were

87. See Regents of the Univ. of Cal. v. Bakke, 438 U.S. 265, 307 (1978). Powell was, of course, striking at a straw man. Neither the Regents nor any of the many amici who filed briefs in their support argued that race-sensitive admission policies are justifiable because of an arbitrary decision to prefer the members of one or another racial or ethnic group. 
more salient than they now are, presidents generally made it a practice to include a representative of each of the nation's regions in their cabinets. A similar consideration influenced appointments to the Supreme Court. As regional identifications have faded, others have taken their place. Racial, ethnic, and gender identifications have replaced regional loyalties as the characteristics to which presidents must attend in making appointments. But though the characteristics are different, the political point of the practice assuring citizens that the groups with which they most strongly identify are socially valued - remains the same.

Minority preferences may be seen as serving much the same purpose. In relation to the black population as a whole, the number who directly benefit from race-sensitive admission policies is infinitesimally small. Nor is there yet persuasive evidence of indirect benefits to any substantial number of African Americans. Yet, the presence of other members of their race in selective colleges and universities and in the positions to which graduation from those institutions leads may, for many, offer meaningful assurance that blacks are valued members of American society - that they have become, or at least have a realistic prospect of becoming, full participants in American life. The point is akin to that often made about the importance of a black presence in the administration of the criminal justice system. Black lawyers, judges, and police officers are necessary not only to provide assurance that the system will operate fairly, though they surely are necessary for that purpose, but to avoid the sense that blacks, whether victims or (alleged) perpetrators, are simply the subjects of an alien occupying force. Similar considerations may require the visible presence of African Americans in the full range of socially valued positions. At present and for the foreseeable future, however, that presence cannot be achieved without race-sensitive selection policies.

The argument that the central institutions of American life must, for these reasons, attend to race in distributing social benefits has considerable force. Over the years, I have come to believe that it may be the most important, perhaps the only persuasive, justification for minority preferences in college and university admissions, in employment, and perhaps in other public and private decisions. But the argument also raises the most troubling objection to such preferences. It is one thing to accept that representation at the highest levels of government is necessary to provide assurances of acceptance to groups whose members feel socially insecure. It is quite another to accept that such groups must, without regard to considerations of merit or desert, be represented in all socially valued positions. The latter requires revision, quite possibly abandonment, of ideals and values fundamental to the character of American society. The ideal of "careers open to talents" has been 
central to the openness of American society to successive waves of immigrants. That ideal rests, ultimately, upon the belief that the identity and importance of individuals exists independently of family, inherited social position, and other imposed characteristics such as race and ethnicity. No one familiar with American history would deny that the ideal has very often been honored only in the breach. Nevertheless, the importance of the ideal cannot be doubted. Especially in the years following the Second World War, the ideal has had a shaping effect upon American law and upon the behavior of American institutions, not least in its influence upon the belated willingness of white Americans to accept that it applies to members of other races. Yet, neither the ideal nor the premises upon which it rests coexist easily with the view that racial representation should be a factor in the distribution of all social goods.

Proponents of racial preferences have at times attempted to blunt the force of that concern by contending that the policies are only temporary, a short-term expedient necessary to overcome the deficits attributable to centuries of oppression. The late Justice Thurgood Marshall saw more clearly. John Jeffries, Lewis Powell's biographer, reports that in the course of the Supreme Court's deliberations in Bakke Justice Stevens argued that "preferences might be acceptable as a temporary measure but not as a permanent solution," adding that "[p]erhaps . . . blacks would not need these special programs much longer." Justice Marshall, however, "broke in to say that it would be another hundred years." 88 Nearly a quarter century later, and thirty-five years after the introduction of preferences, Marshall's estimate does not seem excessive. Although the academic performance of African Americans is improving (pp. 30, 68 ), it is nonetheless true, as Bowen and Bok write, that the substantial disparities in academic performance between blacks and whites "show no signs of disappearing in the foreseeable future" ( $p$. 51).

Social practices that endure for many years, at least those that are as important and as pervasive as the current system of racial preferences, require a set of supporting ideas. The current assault on intellectual standards mounted by the self-styled "critical race theorists," admirably described by Daniel Farber and Suzanna Sherry in their fine little book Beyond All Reason, ${ }^{89}$ is one attempt to provide ideas that will support and enlarge those practices. The root idea of the critical race theorists is that intellectual standards are merely mechanisms of oppression, the means by which a dominant class - that is, white males - maintains its position of social

88. John C. JefFries JR., Justice Lewis F. Powell, JR. 487 (1994).

89. Daniel A. Farber \& Suzanna Sherry, Beyond All Reason: The Radical Assault on Truth IN AMERican Law (1997). 
and economic superiority. The old saw that "knowledge is power" thus takes on new meaning: knowledge does not lead to power; power determines what is knowledge. Reasoned argument and the acquisition of evidence to support empirical claims are not paths to knowledge. They are merely characteristics of discourse that white men value because they draw upon the "tendencies, skills, or attributes of white America." 90 It follows that merit standards for student admissions and faculty appointments are but a "gate built by a white male hegemony that requires a password in the white man's voice for passage."91 They are, to put the point more simply, "white people's affirmative action."92

To be sure, save for the racial turn, these ideas are staples of postmodernism, not the creation of critical race theorists. But especially in the United States, the attractive force of postmodernism owes much to the moral claims that African Americans make upon American society. For some, white and black, the strength of those claims leads to an insufficiently critical acceptance of any ideas that, they imagine, offer hope of improving the conditions of life of American blacks, without regard to the wreckage that may ensue. The attraction of postmodernism is that it offers a set of ideas that, if accepted, would break down a major barrier to entry into institutions that play a central role in American life. If intellectual standards are merely obstacles constructed by "white America" to exclude African Americans and other "people of color" (except those of Asian ancestry) from prestigious colleges and universities, revealing their true nature holds the promise of increasing the representation of those minorities in such institutions. And those who do gain entry, or who already have, will be freed from the demeaning assumption that they somehow fail to "measure up."

No doubt, most proponents of minority preferences do not hold these ideas and ought not to be tarred with the excesses of the critical race theorists and others intellectually allied with them. I raise the postmodernist challenge to intellectual standards only to indicate the breadth and radical character of the framework of ideas likely to be required if such preferences are to remain an enduring feature of American life. The arguments for racial and ethnic diversity now so prominent in educational circles are not adequate to support the full range of practices for which advocates of racial and ethnic preference contend. They do not explain why race or ethnicity should be regarded as relevant to decisions about the employ-

90. John O. Calmore, Critical Race Theory, Archie Shepp, and Fire Music: Securing an Authentic Intellectual Life in a Multicultural World, 65 S. CAL. L. REv. 2129, 2219 (1992).

91. Alex M. Johnson Jr., The New Voice of Color, 100 YALE L.J. 2007, 2052 (1991).

92. Richard Delgado, Rodrigo's Chronicle, 101 YALE L.J. 1357, 1364 (1992) (reviewing Dinesh D'SOUZA, ILIIBERAL Education (1991)). 
ment of mathematics professors, the selection of government contractors, or the establishment of automobile dealerships. Without an adequate framework of supporting ideas, one that is capable of replacing long established and widely held ideals about the distribution of social goods, such decisions are bound to appear as questionable departures from some of the nation's most important values.

The expanding claims for racial representation in all socially valued positions thus poses a significant dilemma. ${ }^{93}$ On the one hand, achieving such representation may well be necessary to social stability. Claims made by a group that constitutes an eighth of the population cannot be ignored, especially when the claims rest upon a moral foundation as compelling as that which underlies the claims made by African Americans. On the other hand, under present circumstances and for the foreseeable future, those claims cannot be met without sacrificing profoundly important ideals and values. Few, if any, issues confronting the nation are as important to its future as those posed by the need to respond to that dilemma.

\section{CONCLUSION}

Several years before the Supreme Court's decision in Bakke, I published an article arguing that minority preferences in public institutions of higher education should not be held unconstitutional. ${ }^{94}$ Although I would not now write the article in precisely the same way, my conclusion remains the same and to some extent for the same reasons. Our constitutional tradition does not speak to the issues posed with sufficient clarity to justify the Court withdrawing the question from the political process. But there is another and perhaps more important reason for allowing the question to be answered politically. Minority preferences, in higher education and elsewhere, have been a pervasive feature of American life for three decades. In Planned Parenthood v. Casey, Justices Kennedy, O'Connor, and Souter declined to overrule Roe $v$. Wade in part because, for many women, the freedom to choose had come to "define their views of themselves and their places in society."95 The

93. The claims now extend to positions that traditionally have been open only to those who achieve at the highest levels, including those that are only honorific. The NAACP and other organizations, for example, have recently been highly critical of Supreme Court justices for hiring very few African-American law clerks. So far as one can tell from news reports, the critics do not regard it important to consider how many African Americans have performed academically at a level that would have brought them within the pool of exceptionally high-achieving law school graduates from which the justices draw their clerks. Similarly, organizations such as the American Academy of Arts and Sciences, election to which is merely honorific, are under pressure to increase their minority representation.

94. See Sandalow, supra note 8 , passim.

95. 505 U.S. 833, 856 (1992). 
Court should not, they argued, ignore the cost of overruling that decision "for people who have ordered their thinking and living around that case."96 Race-sensitive admission policies and other minority preferences have a similar symbolic significance for many African Americans. A Supreme Court decision invalidating all such policies would be understood by many, however incorrectly, as a retreat from promises made during the 1960s to end the oppression of America's black citizens. The late Judge Leon Higginbotham's reaction to the Hopwood decision - "I sometimes feel as if I am watching justice die" 97 - exemplifies the depth of feeling such a ruling would be likely to engender.

The virtue of the political process is that it need not and surely would not confront the question head on. It permits the nation to temporize and compromise at a time when neither alternative either retention or elimination of the policies - appears entirely acceptable. Some states may, as California and Washington have already done, act to end policies of racial preference, but others undoubtedly will not. The action of a few states is unlikely to engender as strong a reaction as a national ban. At the same time, the experience of those states may help to point the way to an answer to the dilemma that is not now apparent. Of no less significance, the division among the states may help to keep alive both a needed assurance to the nation's black citizens that American life is fully open to them and an awareness of the costs and risks of doing so in the way we now do. Muddling through is not intellectually satisfying, but it may be the best we can now hope for.

96. 505 U.S. at 856.

97. A. Leon Higginbotham, Breaking Thurgood Marshall's Promise, N.Y. Times, Jan. 18, $1998, \S 6$, at 28 . 